\title{
Lack of Association between Body Weight, Bone Mineral Density and Vitamin D Receptor Gene Polymorphism in Normal and Osteoporotic Women
}

\author{
Massimo Poggi ${ }^{1}$, Stefano Aterini ${ }^{2,4}$, \\ Laura Nicastro ${ }^{2}$, Vincenzo Chiarugi ${ }^{2}$, \\ Marco Ruggiero $^{2, \#}$, Stefania Pacini ${ }^{3}$ \\ and Massimo Gulisano ${ }^{3}$ \\ ${ }^{1}$ Orthopedic and Traumatic Centre, Careggi \\ Hospital, Firenze, Italy \\ ${ }^{2}$ Department of Experimental Pathology and \\ Oncology, University of Firenze, Italy \\ ${ }^{3}$ Department of Anatomy and Histology, \\ University of Firenze, Italy \\ ${ }^{4}$ Present address: Misericordia e Dolce \\ Hospital, Prato, Italy
}

\begin{abstract}
In an ethnically homogeneous population of women living in Tuscany, Italy, the relationships between age, body weight, bone mineral density and the vitamin D receptor (VDR) gene polymorphism were studied, with the objective of recognizing patients at risk for osteoporosis. In 275 women bone mineral density was measured by Dual Energy X-rays Absorptiometry (DEXA). In 50 of them the individual genetic pattern for VDR was evaluated by DNA extraction followed by PCR amplification of the VDR gene, and digestion with the restriction enzyme BsmI. Age and bone mineral density were inversely related $\left(\mathrm{R}^{2}=0.298\right)$. Body weight was associated with bone mineral density $\left(\mathrm{R}^{2}=0.059\right)$, but not with age. In osteoporotic women, mean $( \pm \mathrm{SD})$ body weight was $59.9 \pm 6.5 \mathrm{Kg}$, lower than that recorded in non osteoporotic women $(64.2 \pm 9.4 \mathrm{Kg})$, even though not significantly different $(p=0.18)$. No association was found between VDR gene polymorphism, bone density or body weight. The performance of anthropometric and genetic components appear to be poor, and,
\end{abstract}

\footnotetext{
\# Correspondence: Prof. Marco Ruggiero, Istituto di Patologia Generale, Viale Morgagni 50, 50134 Firenze, Italy, Tel.: +39 055 411131, Fax: +39 055 416908, E-mail: ak.47@pratonext.it.
}

at least for the time being, bone mineral density measurement by means of MOC-DEXA represents the optimal method to detect women at risk for postmenopausal osteoporosis.

KEYWORDS: Osteoporosis, vitamin D receptor, vitamin D receptor gene, bone density, body weight

\section{INTRODUCTION}

The average age of the elderly is increasing world-wide, bringing about the growth in the number of people suffering from osteoporosis, especially women after menopause, and, accordingly, of age-specific fracture rates [2]. Beyond the health issue, the burden of economic and human costs of osteoporotic fractures, especially hip fracture, is escalating dramatically [18]. With regard to the large costs of osteoporotic fractures, it is important to identify people at risk of osteoporosis early in the course of the disease [22]. However, large-scale population screening studies require great human and economic resources and are time consuming. In this regard, the identification of risk factors could help to select people in general population in order to develop screening and preventive strategies. As far as osteoporosis is concerned, risk factors have been proposed to predict low bone mass and risk of fracture in women: age at menopause and its duration, height, weight, age at menarche, diet and lifestyle [7,21]. Common allelic variants in the gene encoding the vitamin $\mathrm{D}$ receptor (VDR) have been described, on the basis of the presence of the BsmI endonuclease restriction site, labelled as $b$, or of its absence, labelled as $B$. VDR genotypes have been related to differences in bone mineral density, suggesting a susceptibility 
to osteoporosis for women with the BB allele variants $[17,19]$, they have also been related to the abnormal parathyroid function observed in primary as well as secondary hyperparathyroidism $[1,5,27]$, and to prostate and breast cancer $[24,26]$. However, controversy surrounds the association between vitamin $\mathrm{D}$ receptor alleles and bone density [6]. Recently, body weight has been proposed to estimate the risk of osteoporosis, a weight of over $71 \mathrm{Kg}$ being associated with a low risk if compared to the reduced bone density measured in women weighing less than $64 \mathrm{Kg}$, at least in a cohort of Swedish women [16]. An association between VDR alleles and body weight has been noted, suggesting that the VDR gene polymorphism may affect bone mass through an influence on body size [4]. Bearing in mind that familial and environmental factors certainly influence bone mass, which is inversely related to the risk of fractures in elderly women, and that the pattern of the VDR allele frequency distribution shows extreme ethnic differences $[14,15]$, we have evaluated the relationship between VDR genotype, body weight and bone mineral density in an ethnically homogeneous female population living in Tuscany, Italy. The aim of the present study is to verify whether the combination of anthropometric factors and genetic analysis can reliably predict bone mineral density to select women who should undergo bone mass measurements to recognize patients at risk for osteoporosis.

\section{METHODS}

We studied 275 Caucasian women, all living in the same geographic area in central Tuscany, Italy, who were between 22 and 86 years of age (mean \pm SD: $57.5 \pm 8.0$ years), randomly chosen among those who were undergoing bone mineral density (BMD) measurements for the local osteoporosis prevention program.

\section{Bone densitometry measurement}

We used computed densitometry applying dual energy X-ray absorpiometry (DEXA), and proc- essed and analyzed the resulting data with dedicated software. Following the most recent studies in the field of osteoporosis, we measured bone mass in the lumbar spine (L1-L4). Thus, the lumbar spine is the elective site for bone mass measurement when looking for genetic factors influencing osteoporosis since the other regions (i.e. proximal femur) are subject to strong environmental influences. The following parameters were measured: area size (area sizes according to the dimension of each vertebra are selected); bone mean density for each area, and the means of all examined areas; percent variations from the calculated bone peak mass; percent variations in comparison with age-matched healthy subjects. In agreement with previous reports [15], women having DEXA measurements below $0.75 \mathrm{~g} / \mathrm{cm}^{2}$ were considered to have osteoporosis. Subjects were excluded if they suffered from metabolic bone disease (hyperparathyroidism, Paget's disease), malabsorption, or had received steroid or antiepileptic therapies.

\section{VDR genotype}

In 50 women, randomly chosen, the genotype analysis of the polymorphism of the VDR gene was performed, according to the method of Morrison et al. [17], slightly modified as follows [1]. Genomic DNA was extracted from blood using an inorganic method, based on Proteinase $\mathrm{K}$ (Sigma Chem. Co., St. Louis, MO, USA) digestion without phenol. About $5 \mathrm{ml}$ of blood were diluted with $35 \mathrm{ml}$ of cold TRIS $20 \mathrm{mM}$-EDTA $5 \mathrm{mM}$, then placed in ice for twenty minutes and centrifuged at $3500 \mathrm{rpm}$ for 15 minutes at low temperature $\left(4^{\circ} \mathrm{C}\right)$. The pellet obtained in this way was resuspended with vortex in 4 or $5 \mathrm{ml}$ of TE 20-5, then brought to volume of $40 \mathrm{ml}$ with the same solution. It was subjected to one or two of these lavages until it had become white. The white pellet was resuspended by vortexing in half the initial volume of blood in TE 20-5. Then Sarcosyl (N-Lauroylsarcosine, sodium salt; Sigma Chem. Co., St. Louis, MO, USA) was added to a final concentration of $1 \%$, gently mixed by hand and finally Proteinase $\mathrm{K}$ was added in a final concentration of $200 \mu \mathrm{g} / \mathrm{ml}$. The 


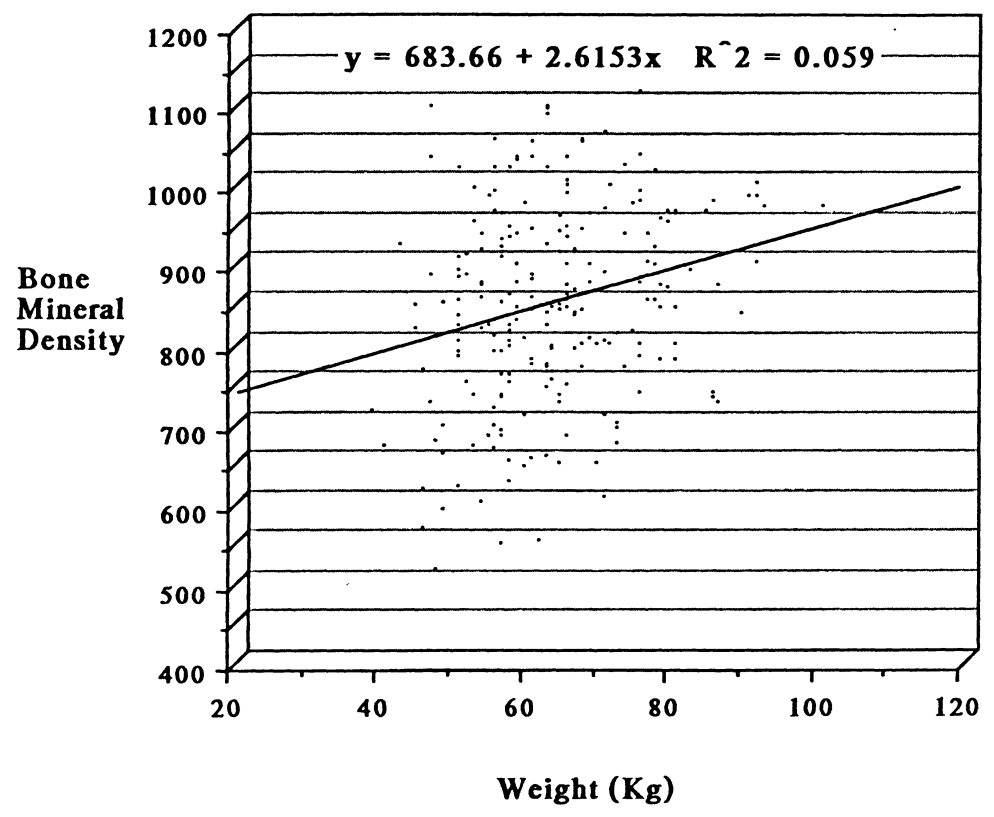

Fig. 1. Relationship between bone mineral density $\left(\mathrm{mg} / \mathrm{cm}^{2}\right)$ and body weight in women.

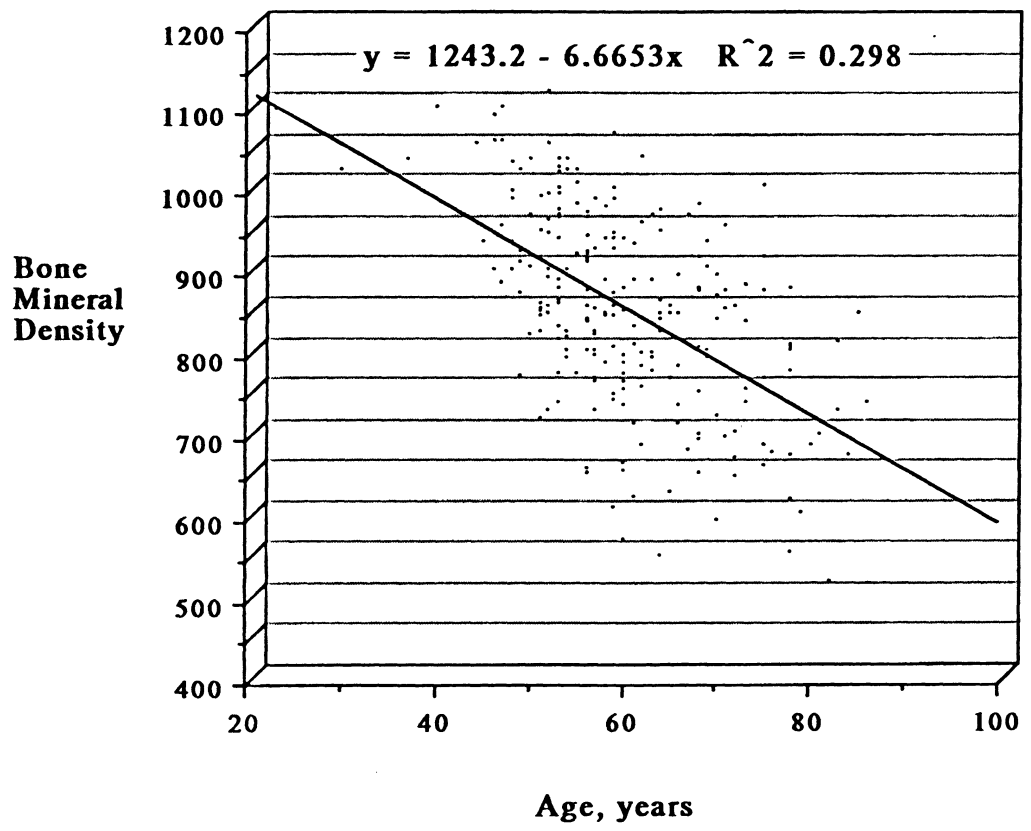

Fig. 2. Age-related diminution of bone mineral density $\left(\mathrm{mg} / \mathrm{cm}^{2}\right)$ in women. 
sample was incubated at $42{ }^{\circ} \mathrm{C}$ overnight in gentle agitation. Ammonium acetate was then added to a final concentration of $3 \mathrm{M}$, mixing well. DNA was then precipitated with cold absolute ethanol twice and finally resuspended in TRIS 20 mM-EDTA $1 \mathrm{mM}$.

\section{Amplification and digestion with restriction enzyme}

PCR of the DNA sequence including the BsmI site was used to determine the genotype of subjects with a MJ Research, Inc. (Watertown, MA, USA) Thermal controller. Genomic DNA was amplified with TaqPolymerase (Polymed, Firenze, Italy), and gene specific primers of 30 and $23 \mathrm{bp}$, during 32 cycles. Each cycle consisted of denaturation at $95{ }^{\circ} \mathrm{C}$ for $1 \mathrm{~min}$, annealing at $55^{\circ} \mathrm{C}$ for $1 \mathrm{~min}$, and extension at $72{ }^{\circ} \mathrm{C}$ for 2 min. Reaction mixture contained: $1 \mathrm{x}$ PCR buffer $\left(670 \mathrm{mM}\right.$ TrisHcl-pH 8.8 at $25^{\circ} \mathrm{C}$; $160 \mathrm{mM}\left(\mathrm{NH}_{4}\right)_{2} \mathrm{SO}_{4} ; 0.1 \%$ Tween-20), $\mathrm{MgCl}_{2}$ ( $2 \mathrm{mM})$, dNTP $(200 \mu \mathrm{m}$ of each), $9.6 \mathrm{ng} / \mu \mathrm{l}$ of each primer and 2.0 units of PolyTaqDNA Polymerase. Amplified DNA was analyzed on a $2 \%$ agarose gel: a single $870 \mathrm{bp}$ band was obtained. Then $10 \mu \mathrm{l}$ of the amplified DNA was restricted with BsmI (3 U) in the appropriate reaction buffer 1x provided by "Celbio", Milan, Italy, according to the suppliers' specification. In order to avoid technical problems with the assay, either unequal amplification of VDR BsmI alleles or incomplete digestion, adequate controls (i.e. amplification and digestion of DNA from subjects with known homozygous or heterozygous genotype) were performed in each assay. Restricted DNA was analyzed on a $2 \%$ agarose gel. Three different patterns of bands could be obtained:

- a single $870 \mathrm{bp}$, corresponding to the amplified DNA without restriction

- a 640bp and a 230bp band, indicating the presence of the restriction site for BsmI

- three bands of 870, 640 and 230bp, indicating a heterozygote genotype.

\section{Statistical analysis}

Results are expressed as means \pm Standard
Deviation. Association between anthropometric, bone measurements and genotype were assessed by analysis of variance and by linear regression analysis, using the statistical analysis program SPSS for Windows, Release 6.0 (SPSS Inc., Chicago, IL, USA).

\section{RESULTS}

Among the 275 examined women, we detected $56(20.3 \%)$ osteoporotic subjects. Body weight was unrelated to age $\left(\mathrm{R}^{2}=0.006\right)$, while it was positively correlated to $\mathrm{BMD}\left(\mathrm{R}^{2}=0.059\right.$; Figure 1). Age and BMD showed an inverse relationship $\left(\mathrm{R}^{2}=0.298\right.$; Figure 2$)$. In the 50 patients whose VDR genotype was examined, 6 homozygous BB (12\%), 9 homozygous bb (18\%) and 35 heterozygous $\mathrm{Bb}(70 \%)$ subjects were found. There were no significant differences in BMD, body weight and age among women with different vitamin $\mathrm{D}$ receptor genotypes (Table 1). No clear role of the different genotypes on BMD was evident, even after adjustment for confounding factors, age and weight, by correction to mean weight and age by regression. In osteoporotic women, mean $( \pm \mathrm{SD})$ body weight was $59.9 \pm 6.5 \mathrm{Kg}$ lower than that recorded in non osteoporotic women, $64.2 \pm 9.4 \mathrm{Kg}$, even though not significantly different $(\mathrm{p}=0.18)$.

\section{DISCUSSION}

In the present study we have investigated the relationship between bone mineral density, anthropometric and genetic factors in a homogeneous group of women living in the same geographic area.

Previous studies have shown that weight loss was associated with a reduction of bone mass, irrespective of age, while subsequent increases or reductions of body weight were followed by similar change of bone density [12]. In American women a weight loss greater than $10 \%$ over 50 years of age was associated with an increased risk of hip fracture, while a weight gain of the similar magnitude reduced the risk of fracture 
Table 1

Patients' anthropometric characteristics, according to vitamin D receptor genotype

\begin{tabular}{cccccc}
\hline VDR genotype & No. of women & $\begin{array}{c}\text { Age } \\
(\mathrm{yr})\end{array}$ & $\begin{array}{c}\text { Body weight } \\
(\mathrm{kg})\end{array}$ & $\begin{array}{c}\text { Bone mineral } \\
\text { density } \\
\left(\mathrm{g} / \mathrm{cm}^{2}\right)\end{array}$ & $\begin{array}{c}\text { Osteoporotic } \\
\text { women }\end{array}$ \\
\hline BB & 6 & $56.2 \pm 3.0$ & $67 \pm 12$ & $0.84 \pm 0.14$ & 2 \\
Bb & 35 & $57.8 \pm 6.5$ & $63 \pm 8$ & $0.88 \pm 0.13$ & 7 \\
bb & 9 & $53.3 \pm 9.3$ & $60 \pm 8$ & $0.91 \pm 0.16$ & 1 \\
$\mathrm{P}$ & & 0.21 & 0.48 & 0.66 & \\
\hline
\end{tabular}

[13]. Notwithstanding, body weight has shown a poor predictive value for identifying women at risk of osteoporosis [10]. It is likely that other unmeasured factors, and especially genetic factors, can explain the modest performance of anthropometric measures. A great body of evidence supports the role of genetic influence in reaching the peak bone mass. In this regard, the polymorphism of the vitamin $\mathrm{D}$ receptor gene has been associated with different bone mineral density [17]. The present results do not support the association of the VDR gene alleles with BMD, because no BMD difference has been measured between women with different VDR genotypes. In this population we found allele frequencies similar to those reported in other studies [9]. However, genotype frequencies are not in HardyWeinberg equilibrium, displaying excess heterozygotes compared to homozygotes. Excess of heterozygotes could be explained by the small number of cases, or by other factors. In fact, other studies on VDR genotype association with different diseases report a percentage of heterozygotes above $50 \%$ in ethnically distinct populations $[8,26]$. Since the VDR genotype is associated with conditions as diverse as tuberculosis, hepatitis B infection, leprosy, prostate cancer, metastatic breast cancer, coronary artery disease, psoriasis, diabetes and sex-dependent growth, one could also hypothesize that in certain populations the heterozygous genotype might have some sort of advantage, thus being overrepresented [3,11,20,23-27]. Recently a meta-analysis of studies dealing with the association between VDR genotype and osteoporosis has revealed a weak association between VDR genotype and bone density [6]. The different behavioural characteristics of subjects might explain the lack of association between vitamin $\mathrm{D}$ receptor alleles and bone mineral density among women in this sample. Moreover, in this population no association has been found between VDR genotype and body weight, differing from previous reports which suggested that the VDR gene polymorphism may affect bone mass through an influence on body size [4]. In fact, in the present study, homozygous bb women showed the highest mean BMD but the lowest mean body weight among the three VDR genotype groups. Independently from the genetic component, mean body weight in osteoporotic women, even though lower, was not significantly different from that measured in non-osteoporotic subjects.

In conclusion, anthropometric and genetic factors, alone or in combination, are poor predictors of bone disease. On the other hand, given the established and sound association between low bone mineral density and increased risk of fracture, the actual measure of bone mineral density by means of MOC-DEXA stands as the best and safest method to identify women affected by osteoporosis and at risk of fracture, even though other factors may contribute to the risk itself.

\section{Acknowledgments}

This study was supported by grants from the Ministero dell'Università e della Ricerca Scientifica e Tecnologica (MURST). We are indebted to Ms. Sophie Minns for assistance in editing and preparing the manuscript. 


\section{References}

[1] Aterini, S., Salvadori, M., Ippolito, E., Petrocelli, P., Pacini, S., Sineo, L., Martini, R., Failli, M., Amato, M. and Ruggiero, M. The role of vitamin $\mathrm{D}$ receptor gene alleles in the secondary hyperparathyroidism of hemodialysis patients. J. Nephrol. 9, (1996) 201-206.

[2] Avioli, L.V. Significance of osteoporosis: a growing international health care problem. Calcif. Tissue Int. 49, (1991) S5-S7.

[3] Bellamy, R., Ruwende, C., Corrah, T., McAdam, K.P., Thursz, M., Whittle, H.C. and Hill, A.V. Tubercolosis and chronic hepatitis B virus infection in Africans and variation in the vitamin D receptor gene. J. Infect. Dis. 179, (1999) 721724.

[4] Berger-Lux, M.J., Heaney, R.P., Hayes, J., DeLuca, H.F., Johnson, M.L. and Gong, G. Vitamin $\mathrm{D}$ receptor gene polymorphism, bone mass, body size and vitamin D receptor density. Calcif. Tisue Int. 57, (1995) 161-162.

[5] Carling, T., Kindmark, A., Hellman, P., Lundgren, E., Ljunghall, S., Rastad, J., Akerstrom, G. and Melhus, H. Vitamin D receptor genotypes in primary hyperpara-thyroidism. Nature Med. 1, (1995) 1309-1311.

[6] Cooper, G.S. and Umbach, D.M. Are vitamin D receptor polymorphisms associated with bone mineral density? A meta-analysis. J. Bone Miner. Res. 11, (1996) 1841-1849.

[7] Gärdsell, P., Lindberg, H. and Obrant, K.J. Osteoporosis and heredity. Clin. Orthop. 240, (1989) 164-167.

[8] Garnero, P., Borel, O., Sornay-Rendu, E. and Delmas, P.D. Vitamin D receptor gene polymorphism do not predict bone turnover and bone mass in healthy premenopausal women. J. Bone Miner. Res. 10, (1995) 1283-1288.

[9] Gennari, L., Becherini, L., Masi, L., Gonnelli, S., Cepollaro, C., Martini, S., Mansani, R. and Brandi, M.L. Vitamin D receptor genotypes and intestinal calcium absorption in postmenopausal women. Calcif. Tissue Int. 61, (1997) 460-463.

[10] Hansen, M.A., Overgaard, K., Riis, B.J. and Christiansen, C. Potential risk factors for development of postmenopausal osteoporosis examined over a 12-year period. Osteoporosis Int. 1, (1991) 95-102.

[11] Hitman, G.A., Mannan, N., McDermott M.F., Aganna, E., Ogunkolade, B.W., Hales, C.N. and Boucher, B.J. Vitamin D receptor gene polymorphism influence insulin secretion in Bangladeshi
Asians. Diabetes 47, (1998) 688-690.

[12] Jensen, L.B., Quaade, F. and Sørensen, O.H. Bone loss accompanying voluntary weight loss in obese humans. J. Bone Miner. Res. 9, (1994) 459-463.

[13] Langlois, J.A., Harris, T., Looker, A.C. and Madans, J. Weight change between age 50 years and old age is associated with risk of hip fracture in white women aged 67 years and older. Arch. Intern. Med. 156, (1996) 989-994.

[14] Lim, S.K., Park, Y.S., Park, J.M., Song, Y.D., Lee, E.J., Kim, K.R., Lee, H.C. and Huh, K.B. Lack of association between vitamin $\mathrm{D}$ receptor genotypes and osteoporosis in Koreans. J. Clin. Endocrinol. Metab. 80, (1995) 3677-3681.

[15] Looney, J.E., Yoon, H.K., Fisher, M., Farley, S.M., Farley, J.R., Wergedal, J.E. and Baylink, D.J. Lack of high prevalence of the BB vitamin D receptor genotype in severely osteoporotic women. J. Clin Endocrinol. Metab. 80, (1995) 2158-2162.

[16] Michaelsson, K., Bergstrom, R., Mallmin, H., Holmberg, L., Wolk, A. and Ljunghall, S. Screening for osteopenia and osteoporosis: selection by body composition. Osteoporosis Int. 6, (1996) 120-126.

[17] Morrison, N.A., Qi, C.J., Tokita, A., Kelly, P.J., Krofts, L., Nguyen, T.V., Sambrook, P.N. and Eisman, J.A. Prediction of bone density from calcitriol receptor alleles. Nature 367, (1994) 284287.

[18] Norris, R.J. Medical costs of osteoporosis. Bone 13, (1992) S11-S16.

[19] Pacini, S., Nicastro, L., Aterini, S., Stefani, P. and Ruggiero, M. Determination of the BB vitamin $D$ receptor genotype identifies patients at risk of developing osteoporosis. Radiol. Med. 92 , (1996) 250-254.

[20] Park, B.S., Park, J.S., Lee, D.Y., Youn, J.I. and Kim, I.G. Vitamin D receptor polymorphism is associated with psoriasis. J. Invest. Dermatol. 112, (1998) 113-116.

[21] Ribot, C., Pouillès, J.M., Bonneu, M. and Trémollières, F. Assessment of the risk of postmenopausal osteoporosis using clinical factors. Clin. Endocrinol. 36, (1992) 225-228.

[22] Ross, PD., Heibrun, L.K., Wasnich, R.D., Davis, J.W. and Vogel, J.M. Prospectives: methodologic issues in evaluating risk factors for osteoporotic fractures. J. Bone Min. Res. 4, (1989) 649-656.

[23] Roy, S., Frodsham, A., Saha, B., Hazra, S.K., Mascie-Taylor, C.G. and Hill, A.V. Association of vitamin D receptor genotype with leprosy 
type. J. Infect. Dis. 179, (1999) 187-191.

[24] Ruggiero, M., Pacini, S., Aterini, S., Fallai, C., Ruggiero, C. and Pacini, P. Vitamin D receptor gene polymorphism is associated with metastatic breast cancer. Oncol. Res. 10, (1998) 43-46.

[25] Suarez, F., Zeghoud, F., Rossignol, C., Walrant, O. and Garabedian. M. Association between vitamin D receptor gene polymorphism and sexdependent growth during the first two years of life. J. Clin. Endocrinol. Metab. 82, (1997) 29662970.

[26] Taylor, J.A., Hirvonen, A., Watson, M., Pittman, G., Mohler, J.L. and Bell, D.A. Association of prostate cancer with vitamin $\mathrm{D}$ receptor gene polymorphism. Cancer Res. 56, (1996) 41084110.

[27] Tsukamoto, Y., Heishi, M., Nagaba, Y., Kobayashi, N., Nomura, Y., Takahashi, K. and Tozawa, H. More on hyperparathyroidism and the vitamin D receptor. Nature Med. 2, (1996) 1162.

[28] Van Schooten, F.J., Hirvonen, A., Maas, L.M., De Mol, B.A., Kleinjans, J.C., Bell, D.A. and Durrer, J.D. Putative susceptibility markers of coronary artery disease: association between VDR genotype, smoking, and aromatic DNA adduct levels in human right a trial tissue. FASEB J. 12, (1998) 1409-1417. 


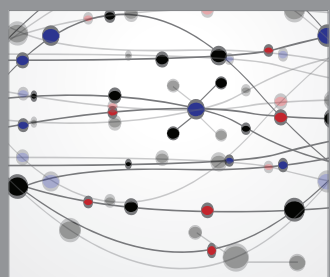

The Scientific World Journal
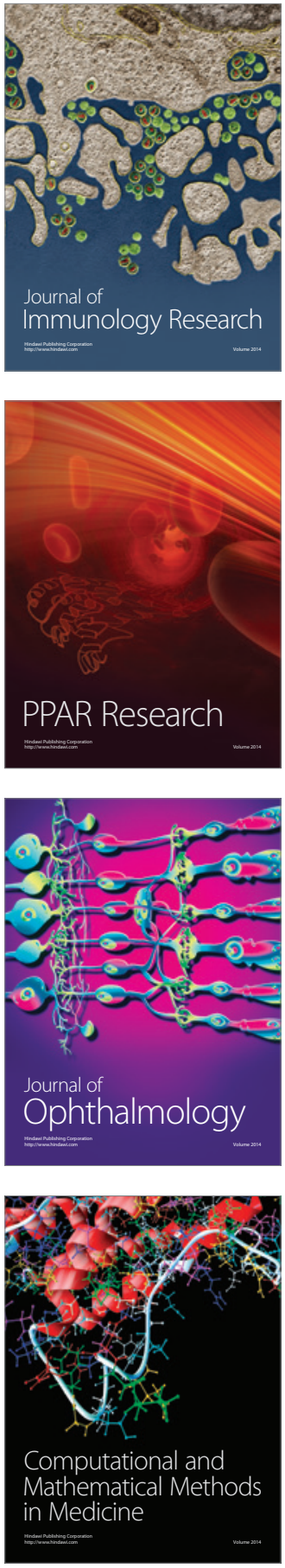

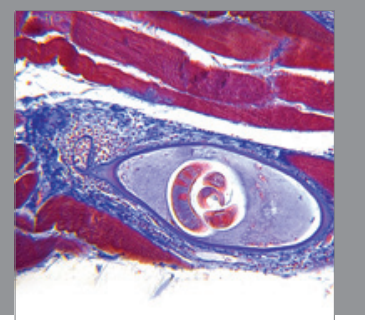

Gastroenterology

Research and Practice
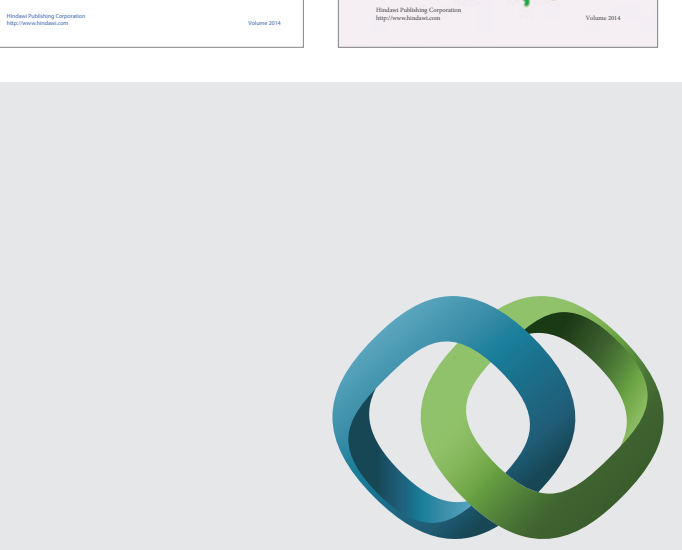

\section{Hindawi}

Submit your manuscripts at

http://www.hindawi.com
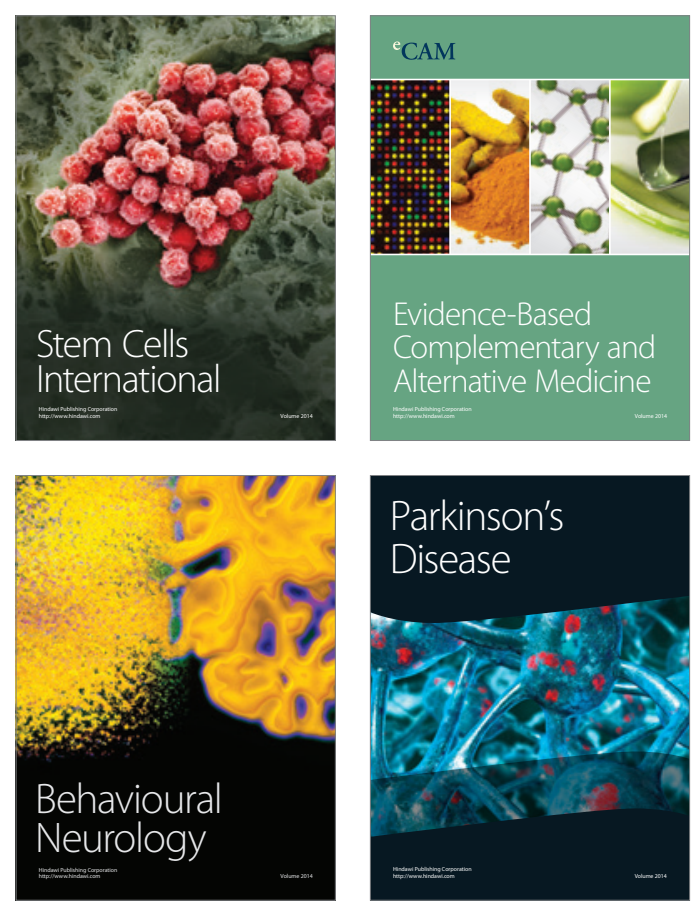

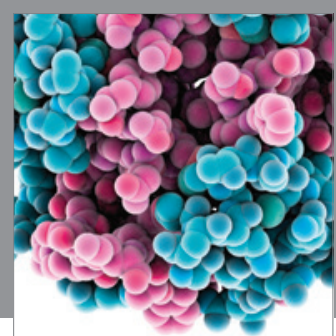

Journal of
Diabetes Research

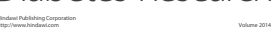

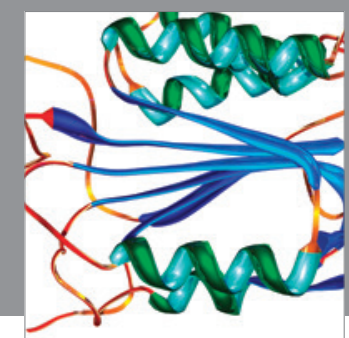

Disease Markers
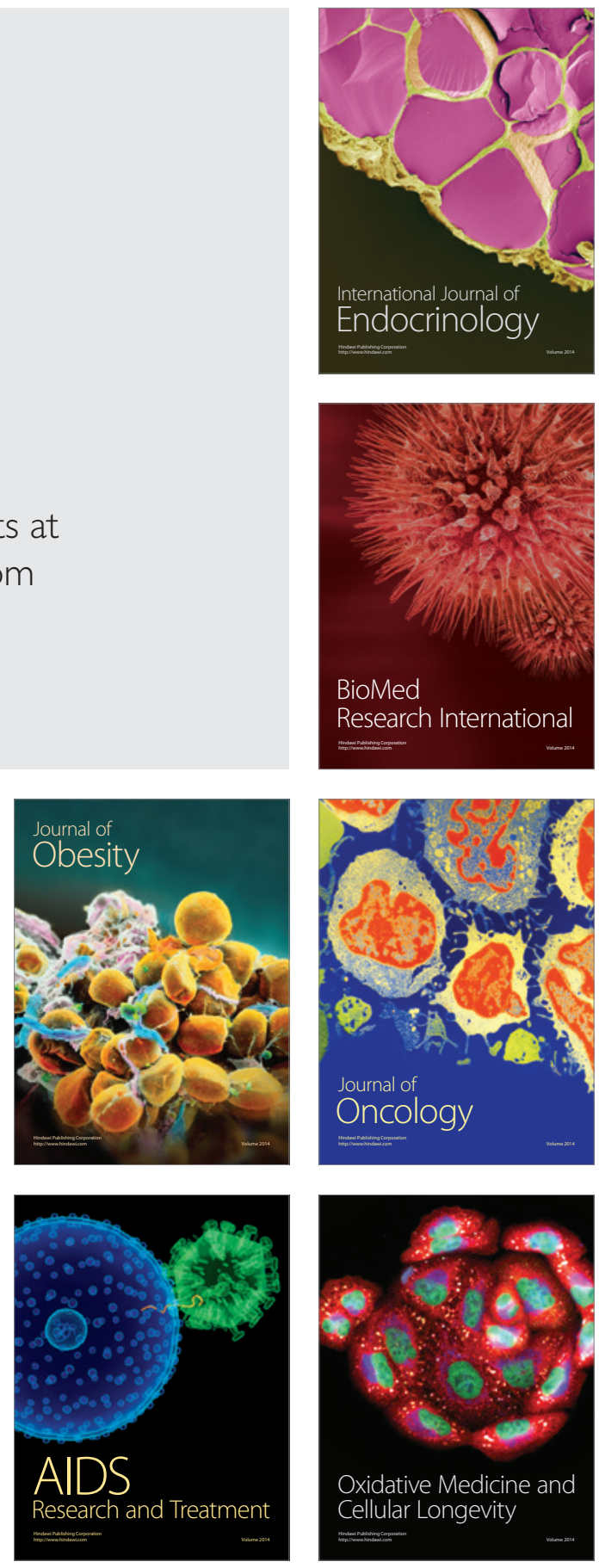